\title{
Interdependence of FDI between India and ASEAN- 5: Evidence from Causality Approach
}

\author{
Rudra P. Pradhan \\ Vinod Gupta School of Management \\ Indian Institute of Technology Kharagpur, India \\ Email: rudrap@vgsom.iitkgp.ernet.in
}

\begin{abstract}
The paper explores the interdependence of FDI between India and ASEAN-5 countries namely, namely Indonesia, Malaysia, Philippines, Singapore and Thailand, at the individual and group level. The empirical analysis is based on time series cointegration and causality test over the period 1970-2008. The findings suggest the presence of interdependence of FDI between India and ASEAN-5 countries. The policy implication of this study is that with the increasing interest of economic integration around the globe, especially with India-ASEAN Regional Trade and Investment Area (RTIA), the existence of interdependence of FDI between member countries is an important feature for maintaining growth sustainability in the Asian economy.
\end{abstract}

Keywords: Economic growth, Defense spending, Panel cointegration

\section{Introduction}

The effect of regional integration on trade flows and foreign direct investment flows are very common in international finance, particularly during the current globalization era. The specialty of regional integration is that it not only creates interdependencies between the countries within the system but also creates interdependencies with other countries in the world. The objective is to increase foreign direct investment (FDI) inflows and trade flows among the member countries. For instance, the Association of Southeast Asian Nations (ASEAN) Free Trade Agreement (AFTA) was designed as a means to increase FDI inflows and to stimulate interregional trade in the Southeast Asia (Kreinin et al., 2008). Similarly, India-ASEAN Regional Trade and Investment Area (RTIA) is designed to stimulate FDI and trade flows among its member countries (Karmakar, 2005). The question is very obvious here how far these countries are very interdependent to each other, particularly on FDI flows and trade flows. The objective of this paper is to study the interdependencies of FDI inflows between India and ASEAN-5 countries, namely Indonesia, Malaysia, Philippines, Singapore and Thailand, at the individual country level and as a whole.

The foreign direct investment (FDI) is one of the fundamental instruments of economic growth. The importance of FDI is, in fact, much higher in the Asian economy because of their inability to generate internal savings in response to their investment needs. One of the most cited reasons for the high economic growth in Asia in the recent era is due to the inflows of FDI in the region. It is one of the most effective ways by which Asian countries are integrated with rest of the world and vice versa. It promotes economic growth by number of ways: (1) increasing the volume of investment and its efficiency; (2) generating technological diffusion from the developed countries to the recipient country; (3) augmenting stock of knowledge in the host country through labour training, skill acquisition and diffusion and the introduction of alternative management practices and organizational arrangements (Vadlamannati et al., 2009; Pradhan, 2006; Li and Liu, 2005; Okamoto and Sjobolm, 2005; Hermes and Lensink, 2003; Zhang and Felmingham, 2002; De Mello, 1999; Borensztein et al., 1998; Balasubramanyam et al., 1996; Chao and Yu, 1994; Grossman and Helpman, 1991). Both India and ASEAN-5 has undergone a progressive economic growth in the last decade and referred as the most dynamic economies in the world (Zhang and Ow, 1996). They share a vital cohesion where both have high dependency on FDI as a tool of export-led growth.

India has recorded immense net inflow of FDI that increased from average annually increment of US\$ 6.9 billion from 1990 to over US\$ 12.8 billion between 2000- 2008. The FDI inflow into India is showing a tremendous upward trend from 1992 onwards and reached US\$ 41.5 billion in 2008. On the contrary, the performance of FDI inflows into ASEAN-5 countries is also very favorable during the recent era, particularly in the 1990s. The region has successfully attracted high volume of FDI since early 1990s, where it is recorded US\$ 66.7 billion in 1996 but the volume declined to US\$ 59.1 billion in 1997 due to Asian Financial Crisis. Nevertheless, the FDI inflows into ASEAN-5 remained favorable with progressive performance and reached US\$ 106.7 billion in 2008 (see Figure 1). Although ASEAN-5 and India become rivalry from the perspective of FDI recipient in the region, 
there is a significant bilateral relationship exist between India and ASEAN-5 (e. g. RTIA). Therefore, the paper likes to examine whether the FDI inflows of India is affected by the FDI inflows of ASEAN-5 countries. The rest of the paper is organized into four different sections. Section II presents literature review; Section III describes the econometric modeling and data descriptions; Section IV discusses the empirical results; and the final section offers the concluding remarks.

\section{Literature Review}

The following section will introduce the theoretical background, and introduce the empirical model that is estimated in this analysis.

Foreign Direct Investment (FDI) plays very key role in development. Its role is manifold and can be analyzed under two different conditions: first, the determinants of FDI on development; second, causality between FDI and development. In the first case, the role of FDI is country specific and can be positive, negative or insignificant, depending on the economic, institutional and technological conditions in the recipient economy (Bhat et al., 2004; Kohpaiboon, 2006). The second case is, however, very diverging, particularly with reference to direction of causality. The divergent is due to time periods, country specifications and partly due to methodological differences. We have literature on both these aspects.

FDI has been widely recognized as a growth-enhancing factor in the host country. It not only a source of capital but also a medium for acquiring skills, technology, organizational and managerial practices and access to markets (Noorbakhsh et al., 2001). FDI introduces advanced technology and that can enhance the technological capability of the host country and hence, generating sustainable economic growth. Most interestingly, the technological benefit is not limited to locally affiliated firms but can also spread to non-affiliated ones. The latter benefit is usually called as technology spillover (Kugler, 2006; Moran, 2001). The process is however not automatic but depends upon country specific factors and policy environment. Moreover, the flows of FDI could be very positive, if there is integration of countries across the world. According to Feenstra and Markusen (1994), FDI determines growth through incorporation of inputs and technological absorptive in the production process. In the first case, output growth can result from the use of a wider range of intermediate goods in FDI related manufacturing. In the second case, FDI is expected to be a potential source of productivity gains via spillovers effects.

Balasubramanyan et al. (1996) find significant positive association between FDI and economic growth and suggest that the above relationship is more holistic in the export promotion policy (EPP) in contrast to import substitution policy (ISP) of a country. In other words, the effect of FDI on economic growth is more attractive under openness in contrast to trade restrictions in the host country. This finding is also similar with the findings of Brecher and Findlay (1983), Bhagwati (1994) and Kokko et al. (2001). The UNCTAD (1999) finds both positive and negative association between FDI and growth, depending upon the incorporation of various variables like infrastructure, market integration, etc. in the model. According to Borensztein et al. (1998), the difference in the technological absorptive ability also makes the variation between FDI and growth across the countries. In their study, human capital plays a very key role in attracting FDI inflows to a host country, as it determines the ability to adopt the foreign technology. The larger the endowment of human capital, the higher is the economic growth via FDI inflows (and vice versa). The study of Xu (2000) ensures that technology transfer provided by US multinationals contributes more productivity growth in the developed countries in contrast to developing countries. This is because most of the developing countries do not have the threshold requirement of human capital and hence, they find difficulty to benefit from inward FDI. That means country must have minimum threshold stock of human capital in order to gain positive effects of FDI. Olofsdotter (1998) finds a positive association between FDI and economic growth and suggests that the association will be much stronger, if the country specific has a higher level of institutional capability and the bureaucratic efficiency.

According to Bengoa and Sanchez-Robles (2003), FDI has a positive association with economic growth, provided the host country must have human capital, economic stability and liberalized markets in order to benefit from long-term FDI inflows. The study by Durham (2004) finds a negative association between FDI and economic growth; but suggests that the effects of FDI are contingent on the absorptive capability of host countries. Bende-Nabende et al. (2003) find significant positive association between FDI and economic growth in the country like Philippines and Thailand and negative association between the two in the country like Japan and Taiwan. This is mostly due to more absorptive capabilities of Japan and Taiwan in contrast to Philippines and Thailand. The negative association between FDI and economic growth also find by Germidis (1977), Mansfield and Romeo (1980), Haddad and Harrison (1993), and Aitken and Harrison (1999). 
The causality approach, on the other hand, mostly focuses on the possibility of endogeneity of the variables. The issue could be bilateral causality or multilateral causality. But our focus is limited to bidirectional causality only. In the below, we highlight few selected studies on the above aspects. Kholdy (1995), applying Granger causality test, finds no causality between the FDI and economic growth but suggests that FDI generates limited efficiency spillovers and an important vehicle for technology transfer. Zhang (1999a), applying causality test, finds the causality between FDI and economic growth in the long run in the country like China, Hong Kong, Indonesia, Japan and Taiwan and in the short run in Singapore. In another study, Zhang (1999b), applying cointegration and error correction models, finds the existence of both a long-run equilibrium between FDI and Economic growth and bidirectional causality between the two in Chinese economy. This finding is also consistent with the findings of Nair-Reichert and Weinhold (2001). Chakrobarty and Basu (2002), applying cointegration and error correction modeling technique, finds a uni- directional causality between FDI and economic growth and that is from economic growth to FDI only. Choe (2003) detects bi- directional causality between FDI and economic growth and suggest that the effect is more from economic growth to FDI. Bhat et al. (2004), applying Granger causality test, find an independent association between FDI and economic growth in the Indian economy. So the relationship between FDI and growth is very controversial. It varies from country to country and even within a country with different time periods (See Hermes and Lensink, 2003; Li and Liu, 2005).

In short, the above literature reflects various aspects of FDI and its integration with growth. The literature is, however, very limited with respect to interdependence of FDI inflows among the various countries. The resent study is, therefore, very keen to investigate the same. In specific, the aim of this paper is to investigate the interdependence of FDI inflows in India with ASEAN-5 by applying the causality approach. The detail description of this approach is given below.

\section{Modelling and Database}

The study of interdependence between FDI of India and FDI of ASEAN-5 is examined in three steps: test of stationarity, test of cointegration and test of causality. The details of these three tests are described below.

\subsection{Test of Stationarity}

The study uses Augmented Dickey Fuller (Dickey and Fuller, 1981; 1986) test to examine the stationarity of the variables. The structure starts with the following time series model.

$$
\Delta Z_{t}=\alpha+\beta Z_{t-i}+\sum_{j=1}^{n} \gamma_{t} \Delta Z_{t-j}+\varepsilon_{t}
$$

Where, $\varepsilon_{t}$ is error term and the null hypothesis is to test whether $\beta$ is equal to zero or not. Though the Augmented Dickey Fuller (ADF) test is very simple and frequent use in econometric analysis, it is not reliable in small samples, because of its poor size and power properties. That means ADF test can over-reject the null hypothesis when it is true and under reject it when it is false (see Dejong et al., 1992; Harris and Sollis, 2003). The study, therefore, uses Dickey Fuller Generalized Least Squares (DFGLS) test (Elliot et al., 1996) and Ng-Perron test (Ng and Perron, 2001) test to check the stationarity. DFGLS is an extension of ADF by de-trending. Assuming that we need to test the order of integration of the variable $Z_{t}$, the DFGLS de-trending test is based testing $\mathrm{H}_{0}$ : $\varphi$ $=0$ in the regression.

$$
\Delta Z_{t}^{d}=\varphi_{0}+\varphi_{1} \Delta Z_{t-1}^{d}+\varphi_{2} \Delta Z_{t-2}^{d}+\ldots \ldots \ldots \ldots . . .+\varphi_{p-1} \Delta Z_{t-p+1}^{d}+\varepsilon_{i, t}
$$

Where, $Z_{t}^{d}$ is the de-trended series. The null hypothesis of the test is that $Z_{t}$ has a random walk trend, possibly with a drift, as follows:

$$
Z_{t}^{d}=Z_{t}-\alpha-\beta t
$$

The DFGLS proposes two alternative hypotheses: (1) $Z_{t}$ is stationary about a linear trend; (2) it is stationary with a (possibly) non-zero mean, but with no linear time trend.

For the first hypothesis, the test is performed by estimating the intercept and trend using the GLS technique. The estimation is performed by generating the following variables.

$$
\begin{aligned}
& \bar{Z}=\left[Z_{1}(1-\bar{\alpha} L) Z_{2}, \ldots \ldots \ldots . .(1-\bar{\alpha} L) Z_{T}\right] \\
& \bar{W}=\left[W_{1}(1-\bar{\alpha} L) W_{2}, \ldots \ldots \ldots . .(1-\bar{\alpha} L) W_{T}\right] \\
& W_{t}=(1, t)^{\prime} \bar{\alpha}=1+\frac{\bar{c}}{T}
\end{aligned}
$$


Where $T$ represents the number of observations for $Z_{t}$ and $\bar{c}$ is fixed (see Elliot et al., 1996). The OLS is performed on the following equation:

$\bar{Z}=\mu_{0} \bar{W}+\mu_{1} W_{t}+\varepsilon_{t}$

And the OLS estimators $\left(\mu_{0}\right.$ and $\left.\mu_{1}\right)$ are utilized for the removal of trend from $Z_{t}$. The ADF test is then applied on the transformed variable by fitting the OLS regression.

$$
\Delta Z_{t}^{d}=\alpha+\beta Z_{t-1}^{d}+\sum_{j=1}^{k} \gamma_{j} \Delta Z_{t-j}^{d}+\varepsilon_{t}
$$

Where, the null hypothesis is to test whether $\beta$ is equal to zero or not.

Now for second hypothesis, we take $\bar{c}=-7$ in the equation of $\bar{\alpha}$ and then compute $\Delta Z_{t}^{d}=Z_{t}-\mu_{0}$.

The ADF regression is fitted on new transformed variables and then null hypothesis is to test whether $\beta$ is equal to zero or not. In both the cases, the tabulated variable is provided by Elliot et al. (1996). Though the DFGLS test is very impressive with power gains, the simulation shows that the test exhibits strong size distortion.

The study, therefore, uses Ng and Perron unit root test to determine the order of integration. The test purposes four test statistics based on the lines of GLS de-trended data. The modelling structure of Ng and Perron unit root test are as follows:

$k=\sum_{t=2}^{T}\left(D_{t-1}^{d}\right)^{2} / T^{2}$

While de-trended GLS tailored statistics are given by

$$
\begin{aligned}
& M Z_{a}^{d}=\left\lfloor T^{-1}\left(D_{T}^{d}\right)^{2}-f_{0}\right\rfloor / 2 k \\
& M Z_{t}^{d}=M Z_{a} X M S B \\
& \operatorname{MSB}^{\mathrm{d}}=\left(\mathrm{k} / \mathrm{f}_{0}\right)^{0.5} \\
& M P_{T}^{D}=\left(\bar{c}^{2} k-\bar{c} T^{1}\right)\left(D_{T}^{d}\right)^{2} / f_{0} \text { if } \mathrm{x}_{\mathrm{t}}=\{1\} \text { and } \\
& M P_{T}^{D}=\left(\bar{c}^{2} k+\left(1-\bar{c} T^{1}\right)\right)\left(D_{T}^{d}\right)^{2} / f_{0} \text { where } \bar{c}=-7 \text { if } \mathrm{x}_{\mathrm{t}}=\{1\} \text { and } \bar{c}=-13.5 \text { if } \mathrm{x}_{\mathrm{t}}=\{1, \mathrm{t}\}
\end{aligned}
$$

Like other tests, the null hypothesis of unit root cannot be rejected, if the test statistic is higher than critical value.

\subsection{Cointegration Test}

When the series becomes stationary at the first difference level, there is possibility of linear combinations between the variables. The test applies to examine the same is known as cointegration (Granger, 1988). Cointegration technique examines whether there exists a long run relationship among the set of integrated variables. Econometric literature, for both univariate and multivariate, has abundant techniques [Engle and Granger, 1987; Engle and Yoo, 1987; Phillips and Hansen, 1990; Johansen, 1988; Johansen and Juselius, 1990] that can examine the long run equilibrium relationship among different time series variables. The study, however, uses Johansen's technique to study the long run equilibrium. The detail of this technique is as follows:

Let $X_{t}$ be a ( $\mathrm{X}$ 1) vector of variables with a sample of t. Assuming $X_{t}$ follows I (1) process, identifying the number of cointegrating vector involves estimation of the vector error correction representation:

$$
\Delta X_{t}=A_{0}+\prod X_{t-p}+\sum_{i=1}^{p-1} A_{i} \Delta X_{t-i}+\varepsilon_{t}
$$

Where, vector $\Delta X_{t}$ and $\Delta X_{t-1}$ are I (1) representation. The long run equilibrium relationship among $X_{t}$ is determined by the rank of $\Pi$ (say $r$ ) is zero, then equation (3) can be transferred to a VAR model of pth order and the variables in level do not have any cointegrating relationship. If $0<\mathrm{r}<\mathrm{n}$, then there are $\mathrm{n} X \mathrm{r}$ matrices of $\alpha$ and $\beta$ such that

$\Pi=\alpha \beta^{\prime}$ 
Where, both $\alpha$ and $\beta$ are ( $\mathrm{n} \times \mathrm{r}$ ) matrices. The cointegrating vectors $\beta$ have the property that $\beta^{\prime} X_{t}$ is stationary [I (0)] even though $X_{t}$ is non-stationary [I (1)]. Johansen likelihood ratio test looks for two statistics: trace statistics and maximum eigen value.

The likelihood ratio test statistic for the null hypothesis that there are at most $r$ cointegrating vectors is the trace test and is computed as:

Trace $=-T \sum_{i=r+1}^{n} \log \left(1-\hat{\lambda}_{i}\right)$

Where $\hat{\lambda}_{r+1}, \ldots . . \hat{\lambda}_{n}$ are (n-r) smallest estimated eigen values. The likelihood ratio test statistic for the null hypothesis of $r$ cointegrating vectors against the alternative of $r+1$ cointegrating vectors is the maximum eigen value test and is given by

$\lambda_{\max }=-T \log \left(1-\hat{\lambda}_{r+1}\right)$

Here, the null hypothesis of $r$ cointegrating vectors is tested against the alternative hypothesis of $r+1$ cointegrating vectors. Hence the null hypothesis $r=0$ is tested against the alternative $r \leq 1, r=1$ against the alternative $r \leq 2$, and so forth. The critical values for boot trace and maximum eigen value statistics are reported in Osterwald- Lenum (1992). It is well known that the cointegartion tests are very sensitive to the choice of lag length. The AIC and SBC has been choosen for the same.

\subsection{Granger Causality Test}

When two variables are cointegrated, the Granger representation theorem suggests that there is possibility of causality between these variables at least in one direction. Engle and Granger (1987), however, cautioned that if the Granger causality test is conducted at first difference through VAR method than it will be misleading in the presence of cointegration. Hence, an inclusion of an additional variable to the VAR method such as an error correction would help us to capture the long run relationship. The detail structure of this VAR model is as follows:

$\left[\begin{array}{l}\Delta I N D I_{t} \\ \Delta I N D O_{t} \\ \Delta M A L A_{t} \\ \Delta P H I L_{t} \\ \Delta S I N G_{t} \\ \Delta \text { THAI }_{t}\end{array}\right]_{t}\left[\begin{array}{l}I N D I_{t-1} \\ I N D O_{t-1} \\ M A L A_{t-1} \\ P H I L_{t-1} \\ \operatorname{SING}_{t-1} \\ \text { THAI }_{t-1}\end{array}\right]+\alpha_{2}\left[\begin{array}{l}I N D I_{t-2} \\ I N D O_{t-2} \\ M A L A_{t-2} \\ P H I L_{t-2} \\ S I N G_{t-2} \\ \text { THAI }_{t-2}\end{array}\right]+\alpha_{3}\left[\begin{array}{l}I N D I_{t-3} \\ I N D O_{t-3} \\ M A L A_{t-3} \\ P H I L_{t-3} \\ S I N G_{t-3} \\ T H A I_{t-3}\end{array}\right]+\left[\begin{array}{l}\zeta_{\text {INDI }} \\ \zeta_{\text {INDO }} \\ \zeta_{\text {MALA }} \\ \zeta_{\text {PHLL }} \\ \zeta_{\text {SING }} \\ \zeta_{\text {THAI }}\end{array}\right]$

Where INDI stands for FDI inflows of India, INDO stands for FDI inflows of Indonesia, MALA stands for FDI inflows of Malaysia, PHIL stands for FDI inflows of Philippines, SING stands for FDI inflows of Singapore, THAI stands for FDI inflows of Thailand. The $\alpha_{0}$ acts as an identity matrix. To test the causal relationship between FDI inflows of two countries, we adopt the modified WALD (MWALD) test proposed by Toda and Yamamoto (1995). The test starts with the FDI inflows between India and Indonesia and than can be generalized to rest of the countries. To test whether INDO FDI inflows does not Granger cause the INDI FDI (if $\mathrm{k}=2$ and $\mathrm{d}_{\max }=1$ ), the null hypothesis is $\mathrm{H}_{0}: \beta_{12}^{1}=\beta_{12}^{2}=0$ where $\beta_{12}^{i}$ are the coefficients of $\mathrm{INDO}_{\mathrm{t}-\mathrm{i}}$ for $\mathrm{i}=1,2 \ldots$ in the first equation of the system. The existence of the causality requires the rejection of the above null hypothesis and that requires the significance of the MWALD statistics for INDO $_{\mathrm{t}-\mathrm{i}}$. Similarly, the null hypothesis can be tested that INDI FDI does not Granger cause INDO FDI. For that, the null hypothesis is $\mathrm{H}_{0}: \beta_{21}^{1}=\beta_{21}^{2}=0$ where $\beta_{21}^{i}$ are the coefficients of $\mathrm{INDO}_{\mathrm{t}-\mathrm{i}}$ for $\mathrm{i}=1,2 \ldots$ in the second equation of the system. The existence of the causality requires the rejection of the above null hypothesis and that requires the significance of the MWALD statistics for INDI $_{t-1}$. The above process can be generalized for the rest of the cases. The annual data of FDI inflows for India and ASEAN-5 countries over the period 1970-2008 are obtained from World Investment Report, UNCTAD, Washington. The data are used in normalized form and their descriptive statistics are reported in Table 1.

\section{Results and Discussion}

Before proceeding to undertake the empirical analysis to test for the interdependence of income, a simple correlation analysis is conducted. The positive correlation indicates that one country's FDI would increase the other country's FDI and the negative correlation indicates one country's FDI would decrease the other country's FDI. The results, presented in Table 1, indicate that there is positive association between India and ASEAN-5 
except Indonesia. The positive correlation is, however, does not indicate the evidence of cointegration or causality between them. Therefore, we investigate the same by the help of cointegration and causality technique. The econometric analysis of this section starts with the stationarity of the time series data and that is the prime requirement for cointegration and causality test. Unit root test has applied to examine the stationarity property of the time series data. It is to be noted that a significant relationship only exists when the variables in the model are in the same order of integration. The estimated results of unit root tests (ADF, DFGLS and Ng-Perron) are reported in Table 2. The results indicate that the computed test statistics could not reject the null hypothesis of stationarity. This confirms that the time series variables are having unit root problems at the level data. That means the variables are non-stationary in their level data and suggests checking the stationarity at a higher order of differencing. However, once the first differences of the variables are considered, the null hypothesis of unit root is rejected at 5\% significance level. This is exclusively true for India and ASEAN-5, namely Indonesia, Malaysia, Philippines, Singapore and Thailand, at individual level and group level. Overwhelmingly, all the testing procedures suggest the existence of unit root or non-stationarity in the level data but found stationary at the first difference. This confirms that the variables are integrated of order one [or I (1)].

Having confirmed the existence of unit roots for all the data series, the next step is to check possibility of long run equilibrium relationship between them. The Johansen's maximum likelihood cointegration test is applied for the same. The estimated results $\left(\lambda_{\text {tra }}\right.$ and $\left.\lambda_{\max }\right)$ are reported in Table 3 at the individual country level and Table 4 at the group level. The null hypothesis of no cointegrating vector in favour of at least one cointegrating vector is rejected at $5 \%$ significance level. The rejection of null hypothesis of no cointegration implies that the countries do not drift apart and share at least a common stochastic trend in the long run. This confirms that there is cointegration, indicating a significant long run relationship between FDI of India and FDI of ASEAN-5. Overall, the results indicate that the variables share a long run co-movement that is bounded by their long run equilibrium relationship.

The cointegrating test is, however, does not provide an indication of causality between India and ASEAN-5. We deploy Granger causality test to detect the direction of causality. The results of Granger causality test based on VAR is reported in Table 4 at the individual country level and Table 5 at the group level. It shows the presence of unidirectional causality from Singapore to India. The estimated F-statistics rejected the null hypothesis of non-causality at $1 \%$ level of significance. This suggests that Singapore's FDI inflows have significant impact on Indian FDI inflows. The findings also show the presence of bidirectional causality between India and Malaysia and between Thailand and India. This suggests that FDI inflows are very interdependent between India, Malaysia and Thailand. That means the FDI of Malaysia and FDI of Indonesia causes the FDI inflows of India. On the contrary, the FDI inflows of India also cause the FDI inflows of Malaysia and FDI inflows of Thailand. We, however, do not find any causality from FDI of India to FDI of Indonesia and FDI of Philippines. In addition to individual member countries of ASEAN, the study finds the bidirectional causality between FDI of India and FDI of ASEAN-5 as a whole. In other words, the FDI of India does Granger cause FDI of ASEAN-5 and vice versa. To complement this study, it is important to investigate whether the above long run relationship that we found are stable over the period of study. We conduct the diagnostic tests for serial correlation (LM test), autoregressive conditional heteroskedasticity (ARCH test), heteroskedasticity (White test) and stability test (Ramsey test). The estimated results are reported in Table 6. The results confirm the stability of the model on the nexus between economic growth and defense spending in the ASEAN- 5 countries.

\section{Conclusion}

The paper empirically examines the interdependence of FDI inflows between India and ASEAN-5 countries, namely Indonesia, Malaysia, Philippines, Singapore and Thailand, at the individual level and group level over the period 1988-2007. The main findings of this study are summarized as follows:

1) FDI inflows are integrated of order one for India and ASEAN-5 countries, namely Indonesia, Malaysia, Philippines, Singapore and Thailand, at the individual level and as a whole.

2) Johansen's multivariate cointegration test confirmed the presence of cointegration between FDI inflows of India and ASEAN- 5, both at the individual level and group level. The multivariate cointegration test indicates that these countries are moving towards long run equilibrium. This evidence brings positive implications towards the establishment of the India-ASEAN Regional Trade and Investment Area (RTIA) in order to enhance the economic and integration between the two.

3) The Granger causality model confirms the presence of causality between FDI of India and FDI of ASEAN-5 at the individual country level and as a whole. At the individual level, Granger causality confirms the presence of unidirectional causality from FDI of Singapore to FDI of India. This suggests that Singapore's FDI 
inflows have significant impact on Indian FDI inflows but not vice versa. The findings also show the presence of bidirectional causality between FDI of India and FDI of Malaysia and between FDI of Thailand and FDI of India. This suggests that FDI inflows are very interdependent between India, Malaysia and Thailand. The study does not find any causality from FDI of India to FDI of Indonesia and FDI of Philippines. But the FDI of Indonesia and FDI of Philippines cause the FDI of Malaysia. At the group level, FDI of India causes FDI of ASEAN-5.

The policy implication is that the existence of interdependence between India and ASEAN-5 is not only boost the capital flows in the member countries but also provides a base for attaining high economic growth in the region. In fact, the current level of interdependence between FDI of India and FDI of ASEAN-5 is high or not, is a secondary issue. What is more important is the degree of commitment these countries would provide and the strong tendency of the intra-blocs of other regions in the world. As the direction of the journey is rather clear for the India- ASEAN-5 relationship that would be an interesting exercises towards the concept of the "Asian Economic Community (EAC)". The other important policy implication is the boost of macroeconomic sustainability in the Asian region. This will provide a tie between them and brings the road towards the broader desire for economic, monetary and financial cooperation in the EAC.

\section{References}

Balasurbramanyam, V. N., Salisu, M. A., and Sapsford, D. (1996). "Foreign Direct Investment and Growth in EP and IS Countries", Economic Journal, 106, 92-105.

Bende-Nabende, A., Ford, J., Santoo, B. and Sen, S. (2003). "The Interaction between FDI, Output and the Spillover Variables: Cointegration and VAR Analysis for APEC, 1965-99", Applied Economics Letters, 10, 165-172.

Bengoa, M. and Sanchez-Robles, B. (2003). "Foreign Direct Investment, Economic Freedom and Growth: New Evidence from Latin America", European Journal of Political Economy, 19, 529-545.

Bhagwati, J. (1994). "Free Trade: Old and New Challenges", Economic Journal, 104, 231-246.

Bhatt, K. S., Tripura, S. C. U. and Raj, K. D. (2004). "Causal Nexus between Foreign Investment and Economic Growth in India", Indian Journal of Economics, 337, 171-185.

Borensztein, E., Gregorio, J. D. and Lee, J. W. (1998). "How Does Foreign Direct Investment Affect Economic Growth", Journal of International Economics, 45, 115-135.

Brecher, R. A. and Findlay, R. (1983). "Tariffs, Foreign Capital and National Welfare with Sector Specific Factors", Journal of International Economics, 14, 277-288.

Chakraborty, C. and Basu, P. (2002). "Foreign Direct Investment and Growth in India: A Cointegration Approach", Applied Economics, 34, 1061-1073.

Chao, C. \& Yu, E. S. H. (1994). Foreign Capital Inflows and welfare in an Economy with Imperfect Competition. Journal of Development Economics, 4, 141-154.

Choe, J. I. (2003). "Do Foreign Direct Investment and Gross Domestic Investment Promote Economic Growth", Review of Development Economics, 7, 44-57.

De Mello, L. R. (1999). Foreign Direct Investment-led Growth: Evidence from Time Series and Panel Data. Oxford Economic Papers, 51, 133-151.

Dejong, D. N., Nankervis, J. C. and Savin, N. E. (1992). Integration versus Trend Stationarity in Time Series, Econometrica, 60, 423-433.

Dickey, D. A. and Fuller, W. A. (1981). Likelihood Ratio Statistics for Autoregressive Time Series with a Unit Root. Econometrica, 49, 1057-1072.

Dickey, D. A., Bell, W. R. and Miller, R. B. (1986). "nit Roots in Time Series Models: Tests and Implications. American Statistician, 40, 12-26.

Durham, J. B. (2004). "Absorptive Capacity and the Effects of Foreign Direct Investment and Equity Foreign Portfolio Investment on Economic Growth" European Economic Review, 48, 285- 306.

Elliot, G., Rothenberg, T. J. and Stock, J. H. (1996). Efficient Tests for an Autoregressive Time Series with Unit Root. Econometrica, 64, 813-836.

Engel, R. F. and Granger, C. W. J. (1987). Cointegration and Error Correction: Representation, Estimation and Testing. Econometrica, 55, 251-276. 
Engel, R. F. and Yoo, B. S. (1987). Forecasting and Testing in Cointegrated Systems. Journal of Econometrics, $35,143-159$.

Feensta, R. C. and Markusen, J. R. (1994)."Accounting for Growth with New Inputs", International Economic Review, 35, 429-497.

Germidis, D. (1977). Transfer of Technology by Multinational Corporations. Paris: Development Centre of Organization for Economic Cooperation and Development.

Granger, C. W. J. (1988). Some Recent Developments in a Concept of Causality. Journal of Econometrics, 39, 199-211.

Grossman, G. M., \& Helpman, E. (1991). Innovation and Growth in the Global Economy. Cambridge, MA: MIT Press.

Haddad, M. and Harrison, A. (1993). "Are There Positive Spillover from Direct Foreign Investment: Evidence from Panel Data for Morocco", Journal of Development Economics, 42, 51-74.

Harris, R. and Sollis, R. (2003). Applied Time Series Modelling and Forecasting. Wiley, West Sussex.

Hermes, N. and Lensink, R. (2003). Foreign Direct Investment, Financial Development and Economic Growth. Journal of Development Studies, 40, 142-163.

Johansen, S. (1988). Statistical Analysis of Cointegrating Vectors. Journal of Economics Dynamic and Control, $12,231-254$.

Johansen, S. and Juselius, K. (1990). Maximum Likelihood Estimation and Inference on Cointegration with Application to the Demand for Money. Oxford Bulletin of Economics and Statistics, 52, 169-210.

Karmakar, S. (2005). India- ASEAN Cooperation in Services- An Overview. Working Paper, No. 176. Indian Council for Research on International Economic Relations, New Delhi.

Kholdy, S. (1995). "Causality between Foreign Investment and Spillover Efficiency", Applied Economics, 27, 745-749.

Kohpaiboon, A. (2006). "Foreign Direct Investment and Technology Spillover: A Cross-Industry Analysis of Thai Manufacturing”, World Development, 34, 541-556.

Kokko, A., Zejan, M. and Tansini, R. (2001). "Trade Regimes and Spillover Effects of FDI: Evidence from Uruguay", Weltwritschaftliches Archiv, 137, 129-149.

Kreinin, M. E. and Plummer, M. C. (2008). Effects of Regional Integration on FDI: An Empirical Approach. Journal of Asian Economics, 19, 447-454.

Kugler, M. (2006). "Spillovers from Foreign Direct Investment: Within or Between Industries", Journal of Development Economics, 80, 444- 477.

Li, X. and Liu, X. (2005). "Foreign Direct Investment and Economic Growth: An Increasingly Endogenous Relationship", World Development, 33, 393-407.

Mansfield, E. and Romeo, A. (1980). "Technology Transfers to Overseas Subsidiaries by US-based Firms", Quarterly Journal of Economics, 95, 737-750.

Moran, T. H. (2001). Parental Supervision: The New Paradigm for Foreign Direct Investment and Development. Washington: Institute for International Economics.

Nair-Reichert, U., Weinhold, D. (2001). "Causality Tests for Cross-Country Panels: A New Look at FDI and Economic Growth in Developing Countries, Oxford Bulletin of Economics and Statistics, 63, 153-171.

Ng, S and Perron, P. (2001). Lag Length Selection and the Construction of Unit Root Test with Good Size and Power, Econometrica, 69, 1519-1554.

Noorbakhsh, F., Paloni, A. and Youssef, A. (2001). "Human Capital and FDI Inflows to Developing Countries: New Empirical Evidence", World Development, 29, 1593-1610.

Okamoto, Y. and Sjoholm, F. (2005). FDI and the Dynamics of Productivity in Indonesian Manufacturing. Journal of Development Studies, 41, 160-182.

Olofsdotter, K. (1998). "Foreign Direct Investment, Country Capabilities and Economic Growth", Weltwitschaftliches Archive, 134, 534-547. 
Osterwald-Lenum, M. (1992). A Note with Quantiles of The Asymptotic Distribution of the Maximum Likelihood Cointegration Rank Test Statistics. Oxford Bulletin of Economics and Statistics, 54, 461-471.

Phillips, P. C. B., and Hansen, B. E. (1990). Statistical Inference in Instrumental Variable Regression with 1 (1) Process. Review of Economic Studies, 57, 99-125.

Pradhan, R. P. (2006). FDI in the Globalization Era: Chinese and Indian Economic Growth. Prajnan, 34, 323-343.

Toda, H. Y. and Yamamoto, T. (1995). Statistical Inference in Vector Auto-regressions with Possibly Integrated Process. Journal of Econometrics, 66, 225-250.

UNCTAD (1999; 2001; 2002; 2005). World Investment Report. New York: United Nations Conference on Trade and Development (UNCTAD).

Vadlamannati, K. C., Tamazian, A., \& Irala, L. R. (2009). Determinants of Foreign Direct Investment and Volatility in South East Asian Economies. Journal of the Asia Pacific Economy, 14, 246-261.

$\mathrm{Xu}$, B. (2000). "Multinational Enterprises, Technology Diffusion, and the Host Country Productivity Growth", Journal of Development Economics, 62, 477-493.

Zhang, K. H. (1999a). "Foreign Direct Investment and Economic: Evidence from Ten East Asian Economics", Economia Internazionale, 51, 517-535.

Zhang, K. H. (1999b). "How Does FDI Interact with Economic Growth in a Large Developing Country? The Case of China", Economic System, 21, 291-304.

Zhang, Q. and Felmingham, B. (2002). The Role of FDI, Exports and Spillover Effects in the Regional Development of China. Journal of Development Studies, 38, 157-178.

Zhang, Z. and Ow, C. H. (1996). Trade Interdependence and Direct Foreign Investment between ASEAN and China. World Development, 24, 155-170.

Table 1

\begin{tabular}{|c|c|c|c|c|c|c|c|c|c|c|c|c|c|c|}
\hline \multirow{2}{*}{$\begin{array}{l}\text { Countries } \\
======== \\
\mathrm{FDI}_{\text {India }}\end{array}$} & \multirow{2}{*}{$\begin{array}{l}\text { Mean } \\
====== \\
1.018\end{array}$} & \multirow{2}{*}{$\begin{array}{l}\text { Med } \\
===== \\
0.262\end{array}$} & \multirow{2}{*}{$===$} & \multirow{2}{*}{$\begin{array}{l}\text { Min Std } \\
======== \\
6.0\end{array}$} & \multirow{2}{*}{$\begin{array}{l}\text { Skew Kur } \\
========= \\
-0.114\end{array}$} & \multicolumn{3}{|c|}{ Correlation Matrix } & \multirow{2}{*}{$\begin{array}{c}===== \\
1.00\end{array}$} & \multirow{2}{*}{$===$} & \multirow{2}{*}{$===$} & \multirow{2}{*}{$===$} & & \\
\hline & & & & & & 1.367 & 1.888 & 6.515 & & & & & & \\
\hline $\mathrm{FDI}_{\text {Indonesia }}$ & 1.006 & 0.784 & & 4.85 & -3.23 & 1.619 & 0.273 & 4.29 & -0.08 & 1.0 & & & & \\
\hline $\mathrm{FDI}_{\text {Malaysia }}$ & 0.999 & 1.003 & & 1.658 & 0.177 & 0.357 & 0.001 & 2.623 & 0.27 & 0.04 & 1.0 & & & \\
\hline FDI $_{\text {Philippines }}$ & 0.994 & 0.926 & & 3.052 & -0.207 & 0.833 & 0.596 & 2.454 & 0.54 & 0.15 & 0.37 & 1.0 & & \\
\hline FDI $_{\text {Singapore }}$ & 1.001 & 0.813 & & 2.466 & 0.331 & 0.579 & 0.896 & 2.999 & 0.67 & 0.33 & 0.21 & 0.65 & 1.0 & \\
\hline $\mathrm{FDI}_{\text {Thailand }}$ & 1.005 & 0.511 & & 4.676 & 0.123 & 1.038 & 1.880 & 6.118 & 0.57 & 0.32 & 0.25 & 0.37 & 0.58 & 1.0 \\
\hline $\mathrm{FDI}_{\mathrm{ASEAN}-5}$ & 1.001 & 0.94 & & 2.184 & 0.392 & 0.433 & 1.017 & 3.863 & & & & & & \\
\hline
\end{tabular}

Note: Med: Median; max: Maximum; Min: Minimum; Std: Standard Deviation; Skew: Skewness; Kur: Kurtosis.

Table 2. Unit Root Test Results

\begin{tabular}{|c|c|c|c|c|c|}
\hline \multirow[t]{2}{*}{ Variables } & \multicolumn{2}{|c|}{ ADF Test } & \multicolumn{2}{|c|}{ DFGLS Test } & \multirow[t]{2}{*}{ Conclusion } \\
\hline & Level & First Difference & Level & First Difference & \\
\hline India & 2.911 & $-4.149 *$ & 0.484 & $-2.852 *$ & $1(1)$ \\
\hline Indonesia & -3.00 & $-9.669 *$ & -2.693 & $-6.756^{*}$ & $1(1)$ \\
\hline Malaysia & -3.543 & $-8.195 *$ & -3.592 & $-7.844^{*}$ & $1(1)$ \\
\hline Philippines & -2.905 & $-5.810 *$ & -2.510 & $-5.920 *$ & $1(1)$ \\
\hline Singapore & -2.533 & $-6.674 *$ & -2.340 & $-6.371 *$ & $1(1)$ \\
\hline Thailand & -3.436 & $-6.366^{*}$ & -3.494 & $-6.528 *$ & $1(1)$ \\
\hline \multirow[t]{2}{*}{ ASEAN-5 } & -1.87 & $-5.260 *$ & -1.76 & $-4.854^{*}$ & $1(1)$ \\
\hline & \multicolumn{5}{|c|}{ Ng-Perron Test } \\
\hline \multicolumn{6}{|l|}{ Level } \\
\hline & $\mathrm{MZ}_{\mathrm{a}}$ & $\mathrm{MZ}_{\mathrm{t}}$ & MSB & MPT & \\
\hline India & -0.50 & -0.11 & 0.222 & 8.895 & \\
\hline Indonesia & -10.13 & -2.24 & 0.222 & 2.428 & \\
\hline Malaysia & -14.71 & -2.682 & 0.182 & 1.78 & \\
\hline
\end{tabular}


Table 2 continued

\begin{tabular}{|l|l|l|l|l|l|}
\hline Philippines & -9.126 & -2.122 & 0.233 & 2.738 & \\
\hline Singapore & -8.513 & -2.018 & 0.237 & 3.047 & \\
\hline Thailand & -14.09 & -2.654 & 0.188 & 6.470 & \\
\hline ASEAN-5 & -5.64 & -1.596 & 0.283 & 4.582 & \\
\hline At First Difference & $-4.89^{*}$ & -1.213 & 0.246 & $16.84^{*}$ & $1(1)$ \\
\hline India & $-17.92^{*}$ & -2.980 & 0.166 & 1.410 & $1(1)$ \\
\hline Indonesia & $-17.20^{*}$ & -2.930 & 0.17 & 1.430 & $1(1)$ \\
\hline Malaysia & $-225.5^{*}$ & $-10.57^{*}$ & 0.047 & 0.171 & $1(1)$ \\
\hline Philippines & $-18.18^{*}$ & -2.804 & 0.154 & -2.085 & $1(1)$ \\
\hline Singapore & $-18.35^{*}$ & $-3.011^{*}$ & 0.164 & 5.074 & $1(1)$ \\
\hline Thailand & $-18.27^{*}$ & $-2.643^{*}$ & 0.145 & 2.628 & $1(1)$ \\
\hline ASEAN-5 &
\end{tabular}

Note: The parentheses indicate the test statistics at the first difference level; *: Statistically significant at $1 \%$ level; and other notations are defined earlier.

Table 3. Johansen's Cointegration Test Results

\begin{tabular}{|c|c|c|c|}
\hline Null Hypothesis & Alternative Hypothesis & $\lambda_{\text {Tra }}$ & $\lambda_{\text {Max }}$ \\
\hline \multicolumn{4}{|c|}{ At Individual Level } \\
\hline$r=0$ & $\mathrm{r}=1$ & $142.6 *[0.00]$ & $63.104 *[0.00]$ \\
\hline$r \leq 1$ & $\mathrm{r}=2$ & $79.35 *[0.01]$ & $32.753 *[0.01]$ \\
\hline$r \leq 2$ & $\mathrm{r}=3$ & $46.60[0.07]$ & $23.369[0.16]$ \\
\hline$r \leq 3$ & $\mathrm{r}=4$ & $23.23[0.24]$ & $15.575[0.25]$ \\
\hline$r \leq 4$ & $\mathrm{r}=5$ & $7.656[0.50]$ & $7.6220[0.42]$ \\
\hline$r \leq 5$ & $r=6$ & $0.034[0.85]$ & $0.0338[0.85]$ \\
\hline \multicolumn{4}{|c|}{ At Group Level (India and ASEAN-5) } \\
\hline$r=0$ & $\mathrm{r}=1$ & $21.85 *[0.00]$ & $19.81 *[0.00]$ \\
\hline$r \leq 1$ & $\mathrm{r}=2$ & $2.036[0.15]$ & $2.036[0.06]$ \\
\hline
\end{tabular}

Note: $\lambda_{\text {Tra }}$ Trace Statistics; $\lambda_{\text {Max }}$ : Maximum Eigen Value statistics; *: Indicates the probability of significance at $1 \%$.

Table 4. Granger Causality Test Results (At Individual Country Level)

\begin{tabular}{|c|c|c|c|c|c|c|}
\hline \multirow{3}{*}{$\begin{array}{l}\text { Independent Variables } \\
====+========= \\
\text { India }\end{array}$} & \multirow{3}{*}{$\begin{array}{l}\text { INDI } \\
====== \\
------\end{array}$} & \multicolumn{2}{|c|}{ INDOMALA } & \multicolumn{3}{|c|}{ PHIL SING THAI } \\
\hline & & \multicolumn{5}{|c|}{ At $(1,2)$} \\
\hline & & 0.275 & $4.431^{*}$ & 0.979 & 1.058 & $4.864 *$ \\
\hline Indonesia & 1.096 & ------ & $10.42 *$ & 0.577 & 2.069 & 0.008 \\
\hline Malaysia & $5.165^{*}$ & 0.485 & ------ & 2.829 & 1.195 & 0.641 \\
\hline Philippines & 1.592 & 0.678 & $4.443^{*}$ & ------- & 1.882 & 1.243 \\
\hline Singapore & $6.525^{*}$ & $4.956^{*}$ & 1.462 & $4.299 *$ & ------- & 0.234 \\
\hline Thailand & $3.740 * *$ & $5.962 *$ & 1.915 & $4.329^{*}$ & $2.884^{*}$ & ------ \\
\hline \multirow[t]{2}{*}{ Joint } & $18.53 *$ & $15.35^{*}$ & $32.14 *$ & $15.89^{*}$ & $11.35^{*}$ & $10.98^{*}$ \\
\hline & \multicolumn{6}{|c|}{ At $(2,2)$} \\
\hline India & ---- & 0.692 & 0.012 & 0.915 & $4.763 *$ & $10.49 *$ \\
\hline Indonesia & 0.639 & --- & $2.715^{*}$ & 0.019 & 0.482 & 1.392 \\
\hline Malaysia & $2.817^{*}$ & 0.027 & ---- & 1.727 & 1.034 & 0.054 \\
\hline Philippines & 0.904 & 0.001 & 1.571 & ---- & 1.285 & 0.745 \\
\hline Singapore & $7.503^{*}$ & $4.521^{*}$ & 1.444 & $2.367^{*}$ & --- & 0.297 \\
\hline Thailand & $1.937 * *$ & $6.669^{*}$ & 0.761 & 0.090 & 0.072 & --- \\
\hline Joint & $15.20^{*}$ & $12.18^{*}$ & $8.367^{*}$ & $8.305^{*}$ & $10.53 *$ & $20.94 *$ \\
\hline
\end{tabular}

Note: $*(*)$ : Indicates statistically significant at $1 \%(10 \%)$ level. 
Table 5. Granger Causality Test Results (At Individual Country Level)

\begin{tabular}{|c|c|c|}
\hline Independent Variables & INDI & ASEAN-5 \\
\hline \multicolumn{3}{|c|}{ At $(1,2)$} \\
\hline India & ------- & $4.940^{*}$ \\
\hline ASEAN-5 & $2.984 * *$ & ------- \\
\hline Joint & $19.43^{*}$ & $65.22 *$ \\
\hline \multicolumn{3}{|c|}{ At $(2,2)$} \\
\hline India & ------- & $6.739^{*}$ \\
\hline ASEAN-5 & $8.342 *$ & ------- \\
\hline Joint & $16.50 *$ & 94.56* \\
\hline
\end{tabular}

Note: $*(*)$ : Indicates statistically significant at $1 \%(10 \%)$ level.

Table 6. Short Run Diagnostic Tests

\begin{tabular}{|l|l|l|l|l|}
\hline Countries & LM & ARCH & Ramsey & White \\
\hline Indonesia & $136.15^{*}$ & $69.73^{*}$ & $6.23^{*}$ & 0.118 \\
& {$[0.00]$} & {$[0.00]$} & {$[0.00]$} & {$[0.73]$} \\
\hline Malaysia & $48.07^{*}$ & 37.19 & $6.972^{*}$ & 2.842 \\
& {$[0.00]$} & {$[0.00]$} & {$[0.00]$} & {$[0.10]$} \\
\hline Philippines & $9.467^{*}$ & $6.95^{*}$ & 0.983 & 0.23 \\
& {$[0.00]$} & {$[0.01]$} & {$[0.38]$} & {$[0.63]$} \\
\hline Singapore & $17.66^{*}$ & 4.248 & $2.052^{*}$ & 0.848 \\
& {$[0.00]$} & {$[0.02]$} & {$[0.12]$} & {$[0.36]$} \\
\hline Thailand & $8.293^{*}$ & $8.51^{*}$ & $6.385^{*}$ & $7.676^{*}$ \\
& {$[0.00]$} & {$[0.00]$} & {$[0.00]$} & {$[0.00]$} \\
\hline ASEAN & $29.08^{*}$ & $12.36^{*}$ & $5.52^{*}$ & 2.04 \\
& {$[0.00]$} & {$[0.00]$} & {$[0.00]$} & {$[0.16]$} \\
\hline
\end{tabular}

Note: LM: Serial Correlation LM Test; ARCH: ARCH Test; Ramsey: Ramsey Test; White: White Heteroskedasticity Test; the parentheses indicate that the test statistics is significant.

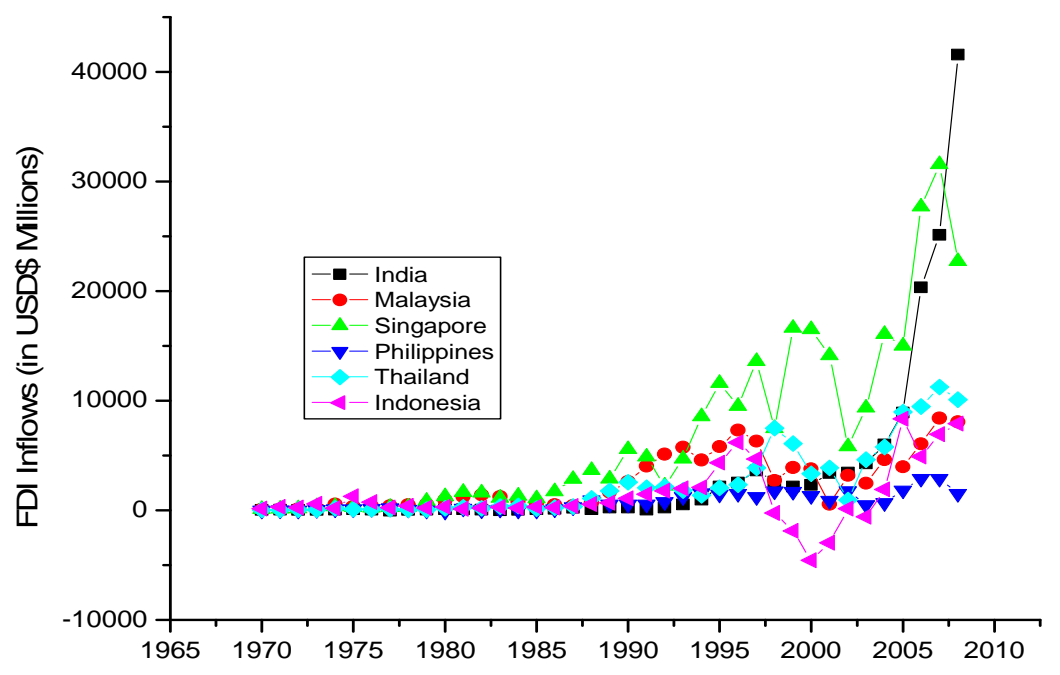

Figure 1. The Visual Plots of FDI between Indian ASEAN-5 